\title{
Life Cycle Assessment (LCA) in Environmental Impact Assessment (EIA): principles and practical implications for industrial projects
}

Magdalena RybaczewskaBlażejowska, Ph.D. Kielce University of Technology, Department of Production Engineering

Dmitry Palekhov, Ph.D. Brandenburg University of Technology Cottbus-Senftenberg, Department of Environmental Planning

\section{Introduction}

Following the formal introduction in the United States in the late 1960s and early 1970s as part of the National Environmental Policy Act (NEPA), the environmental impact assessment (EIA) rapidly gained recognition across the globe and now can be considered as one of the most widespread and commonly used instruments of environmental protection and licencing. Indeed, since the enactment of NEPA more than 40 years ago, at least 120 countries worldwide have established EIA systems and introduced various forms of statutory requirements for the consideration of environmental impacts of development projects (Glasson et al. 2005, $p$ 36). According to the latest amendment of the European EIA Directive, EIA is a process that identifies, describes and assesses the direct and indirect effects of a project on: a) population and human health; b) biodiversity; c) land, soil, water, air and climate; d) material assets, cultural heritage and the landscape; and finally e) the interaction between the 
aforementioned factors Directive 2014/52/EU). The likely significant effects must be considered with regard to their environmental impacts, since the relationship between environmental aspects and environmental impacts has a cause-and-effect nature. Project is defined as the execution of construction works or other installations or schemes as well as other interventions in the natural surroundings and landscape including the extraction of mineral resources (Directive 2011/92/EU).

EIA is the formalised, systematic and comprehensive process that consists of several predetermined steps. The main are: project screening (is an EIA needed?); scoping (what are the key impacts and issues that should be considered in EIA?); description of the project and its alternatives; establishment of the environmental baseline; evaluation of impacts identified during the scoping stage and assessment of their significance; identification of mitigation measures; presentation of EIA findings in the environmental impact statement (EIS, also known as EIA report or environmental report) and its review; decision-making; and finally the post-decision monitoring and audit of predictions and mitigation measures (Glasson et al. 2005, pp. 4-6, 87-194). To ensure the inclusiveness of the process and that the social interests are taken into consideration in the decisionmaking, the public participation and consultations are usually integrated into several steps of the EIA process, e.g. into the scoping and review stages (Jain et al. 2001, pp. 281-307).

The prediction of impacts and the evaluation of their significance is one of the most important steps in the whole EIA process. Following the Directive 2014/52/EU requirements, EIS should provide, amongst others, the following information:

- the use of natural resources, in particular land, soil, water and biodiversity, considering the availability of these resources,

- the emission of pollutants, noise, vibration, light, heat and radiation, the creation of nuisances, and the disposal and recovery of waste,

- the risks to human health, cultural heritage and the environment,

- the impact of the project on climate and the vulnerability of the project to climate change,

- the technologies and the substances used.

Despite the fact that the prediction and the evaluation of impacts forms a very important step of the EIA process "much, if not most, current evaluation of significance of environmental impacts in EIA is simple and often pragmatic, drawing on experience and expert opinion rather than on complex and sophisticated analysis" (Glasson et al. 2005, p. 144). Therefore, the common 
critique of EIA very often comes from lack of defensible foundation for the evaluation of environmental impacts.

This paper aims to propose and execute an alternative approach for the evaluation of the environmental impacts of industrial projects based on the integration of the life cycle assessment (LCA) technique into the EIA process. The current approach is illustrated with a case study of the planned furniture production plant located in Poland. The application of LCA in EIA represents a relatively new approach that, so far, has been essentially discussed in general context. Consequently, Manuilova et al. (2009, pp. 4511-4518) claim that LCA can be applied to validate system boundaries by considering indirect (global and regional) impacts throughout life cycle. The indirect impacts can be sometimes, however, higher than the direct (on-site) ones (Lenzen et al. 2003, pp. 263282). Moreover, Steinemann (2001, pp. 3-21) argues that LCA can support the environmental comparison of alternatives to the evaluated project. The practical use of LCA in the EIA process has hardly been investigated and referred to in a different site and type of project context (Larrey-Lassalle et al. 2017, pp. 95-106; Dąbal, Łyszczarz 2016, pp. 41-50; Li et al. 2009, pp. 766-775).

\section{Materials and methods}

The integrated EIA-LCA approach is applied for the evaluation of the environmental impacts of industrial project. Consequently, there is a need to present the practical aspects of using LCA.

LCA is a technique that addresses the environmental aspects and potential environmental impacts of a product system throughout its life cycle (ISO 14040, 2006). The term product system ought to be understood as the collection of unit processes, performing a defined function that models the life cycle of a product i.e. selected physical goods as well as services and technological processes (ISO 14040, 2006; Guinee 2004, p.6). LCA allows for environmental analysis at various stages of a product's life cycle. Consequently, one can distinguish five basic variants of LCA analysis: cradle-to-grave analysis that covers the entire linear life cycle of the product system, cradle-to-cradle analysis that covers the entire circular life cycle of the product system, gate-to-gate analysis that covers selected stages of the life cycle of the product system, cradle-to-gate analysis that focuses on selected stages of the life cycle of the product system with the addition of upstream environmental impacts and gate-to-grave modelling that focuses on selected stages of the life cycle of the product system with the addition of downstream environmental impacts. 
According to ISO 14040 and ISO 14044 standards, the LCA methodology consists of four phases, namely: the goal and scope definition, inventory analysis (LCI), impact assessment (LCIA) and interpretation of the results (ISO 14040:2006; ISO 14044:2006). The aforementioned LCA phases are closely related to each other as to achieve the systematic assessment of the environmental aspects and potential environmental impacts of the product system. There are three levels of sophistication of LCA studies: screening, simplified and detailed. Due to the fact, however, that the screening LCA research refers just to the generic, secondary data of selected life cycle stages and the detailed LCA research requires very itemised primary data associated with all stages of life cycle, the simplified LCA research is most often applied in practice (Guinee 2004, pp. 464-467).

The LCA analyses provide a number of valuable results that support decisionmakers in industry and the service sector, a government and non-governmental organisations in strategic planning, priority setting and designing (ISO 14044:2006). Therefore, the eco-efficiency analysis, eco-designing, creating ecoinnovations are ones of traditional areas for using LCA. Besides these traditional areas of using LCA, the LCA analyses have recently gained on importance in the context of environmental management, since the revised version of ISO 14001:2015 requires organisations to influence their processes and products from the life cycle perspective (Rybaczewska-Błażejowska 2017, pp. 98-106).

From the description of the EIA requirements and the LCA capabilities results the added value of the integrated EIA-LCA approach in the evaluation of the environmental impacts of industrial projects. It is discussed from the life-cycle perspective (see figure 1). In the first phase, i.e. the goal and scope definition, not only the man-made environmental interventions of a single industrial plant (a central process) are considered, but also the environmental impacts of other parties (upstream and downstream processes) involved in the whole production system. By analogy, the second phase, i.e. LCI, involves the collection and quantification of inputs and outputs of the whole production system with the difference that LCI of the production process of industrial plant relies on primary data whereas the analysis of remaining processes relies on secondary data. The third phase, i.e. LCIA, aimed at estimating the magnitude and significance of the potential environmental man-made interventions of the whole production process. Consequently, it involves a complex sequence of steps, from the man-made interventions (aspects and impacts) to sorting them into classes according to either the effect they have on the environment (impact categories) or the damage they cause to the environment (areas of protection) (see figure 2). 


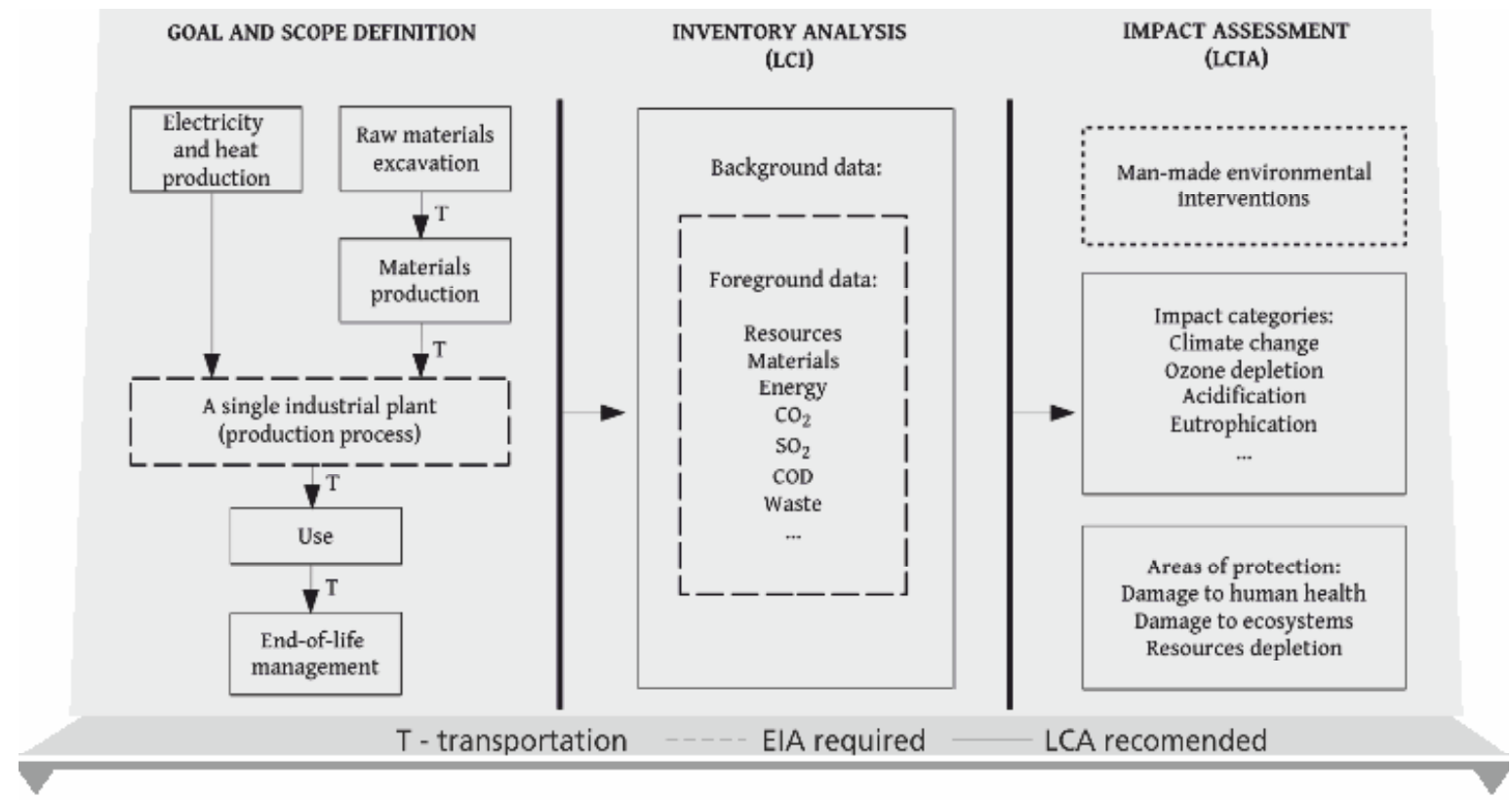

Figure 1. A flowchart of integrated ElA-LCA approach in the evaluation of the environmental impacts

Source: own study

\begin{tabular}{|c|c|}
\hline \multicolumn{2}{|c|}{ Man-made interventions } \\
\hline Aspect & Impact \\
\hline $\begin{array}{l}\text { Green- } \\
\text { house } \\
\text { gasses } \\
\text { emission }\end{array}$ & $\begin{array}{c}\text { Increased } \\
\text { atmospheric } \\
\text { greenhouse } \\
\text { gasses } \\
\text { concentration }\end{array}$ \\
\hline
\end{tabular}

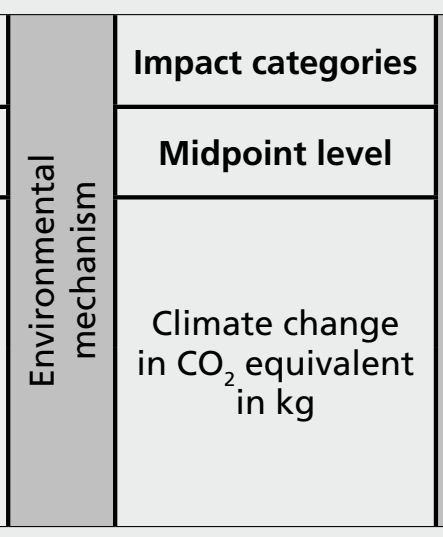

\begin{tabular}{|c|c|}
\hline \multirow{4}{*}{ 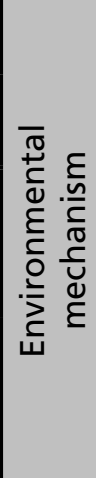 } & Areas of protection \\
\hline & Endpoint level \\
\hline & $\begin{array}{l}\text { Damage to human } \\
\text { health in DALY }\end{array}$ \\
\hline & $\begin{array}{l}\text { Damage to } \\
\text { ecosystems in } \\
\text { SPECIES.YR }\end{array}$ \\
\hline
\end{tabular}

Figure 2. An overview of the intervention - effect - damage chain modelling in LCIA with climate change as an example

Source: own study upon Goedkoop et al. 2013, pp. 21-34 


\section{Results and discussion}

\subsection{Life cycle assessment of the furniture production system}

\subsubsection{Goal and scope definition}

The EIA-LCA analysis aims to evaluate the potential environmental impacts of the expansion of the existing furniture production plant by a new production hall. The new furniture production hall will have an area of $6000 \mathrm{~m}^{2}$ and will be entirely dedicated for the production of residential furniture, such as kitchen, bedroom, living room, bathroom and cabinet furniture. The production process will encompass the following main operations: the storage of materials (wood and fibreboard), the cutting of boards, the milling, the bonding of frames and prepared elements, the veneering of rectilinear and curved planes, the drilling, the assembling, packing and the storage of finished furniture and finally their shipping.

According to the adopted goal of the research, the scope of the EIA-LCA analysis covers the planned production process of residential furniture together

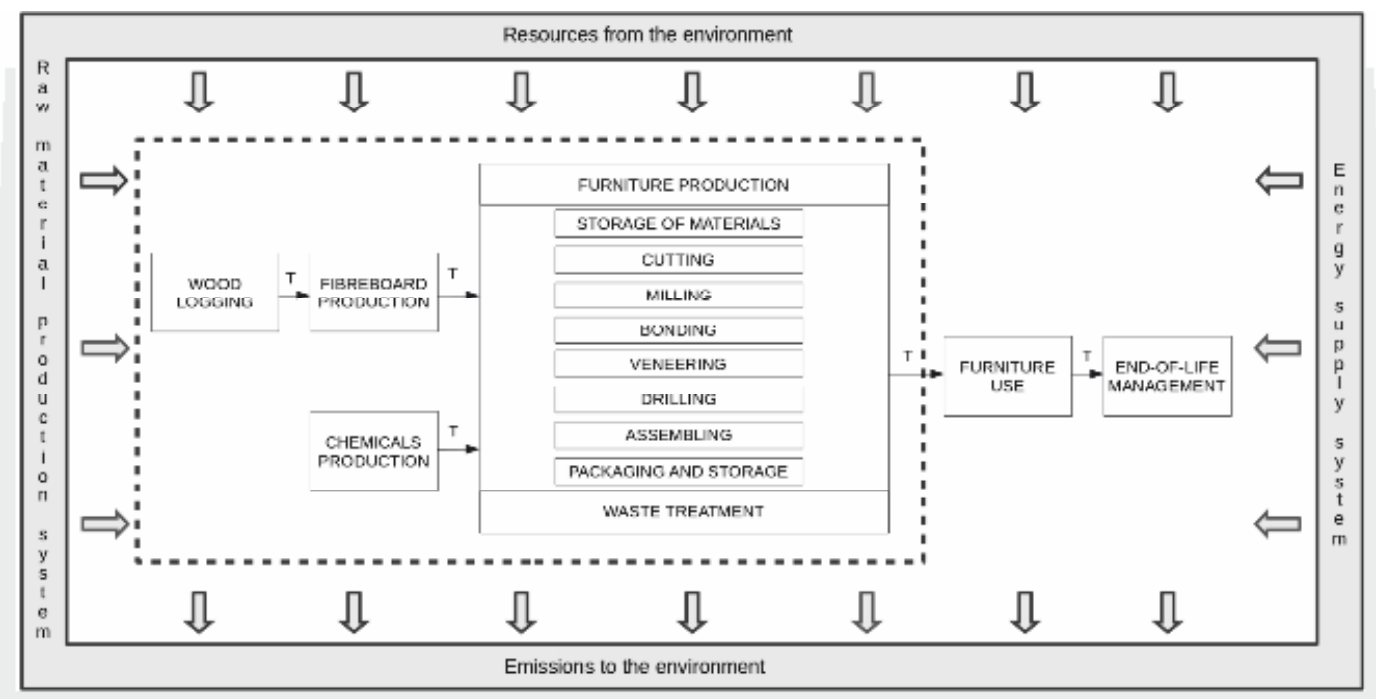

$\mathrm{T}$ - transportation

Figure 3. The system boundaries of the furniture production system and its unit processes

Source: own study 
with the preceding processes, such as: the production of energy, the production of heat, the logging of trees, the production of fibreboards and the production of remaining substances used for the manufacturing of furniture (adhesives, paraffin emulsion, dyes) and thus it is a system level assessment (see figure 3). The phases of furniture use and post-consumption waste management are excluded from the system boundaries; hence it is the conventional simplified cradle-to-gate LCA analysis.

\subsubsection{Inventory analysis}

The inventory analysis of the planned furniture production hall covers, all provided by the investor, inputs and outputs of the analysed furniture production system (see figure 4). Consequently, on the side of the inputs, energy,

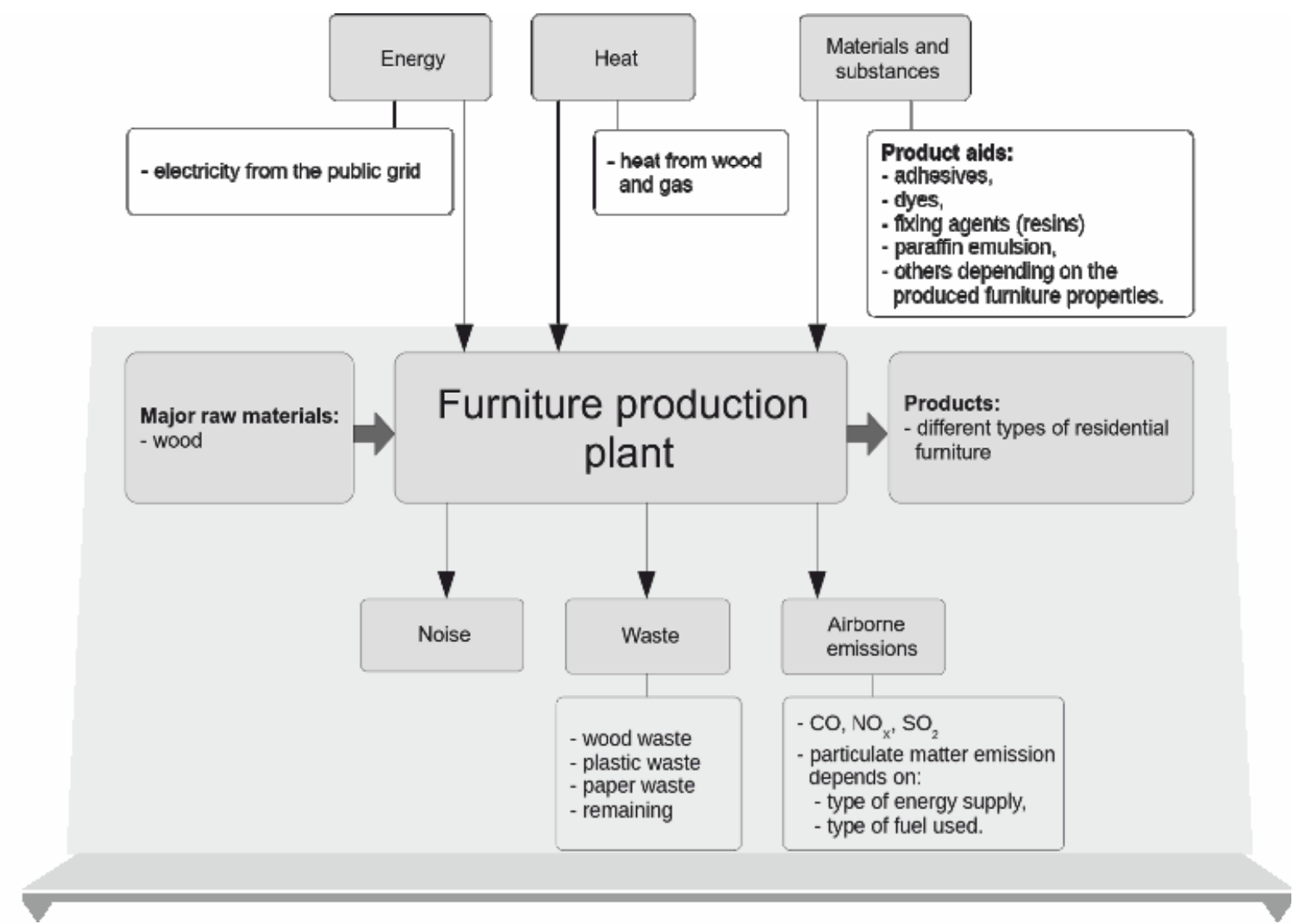

Figure 4. The general scheme of the inventory analysis of the furniture production system

Source: own study 
heat, materials (wood and fibreboards) and substances (e.g. adhesives, paraffin emulsion, dyes) are considered, whereas on the side of the outputs, airborne emissions (e.g. particulate matter, $\mathrm{CO}, \mathrm{NO}_{x}, \mathrm{SO}_{2}$ ) and waste (e.g. wood, plastic and paper waste) are considered. Due to the limitations of the LCIA methods, the noise generated by the furniture productions process and the traffic of incoming and outcoming vehicles is excluded from the LCA analysis. It is estimated that the trucks traffic will be at a level of 25 per day.

\subsubsection{Impact assessment}

The impact assessment of the planned furniture production hall is conducted using one of the most popular LCA software SimaPro and the ReCiPe Endpoint methods. Therefore, the LCI results are classified into three areas of protection: human health, ecosystems and resources that correspond to the following impact categories: climate change (human health and ecosystems), ozone

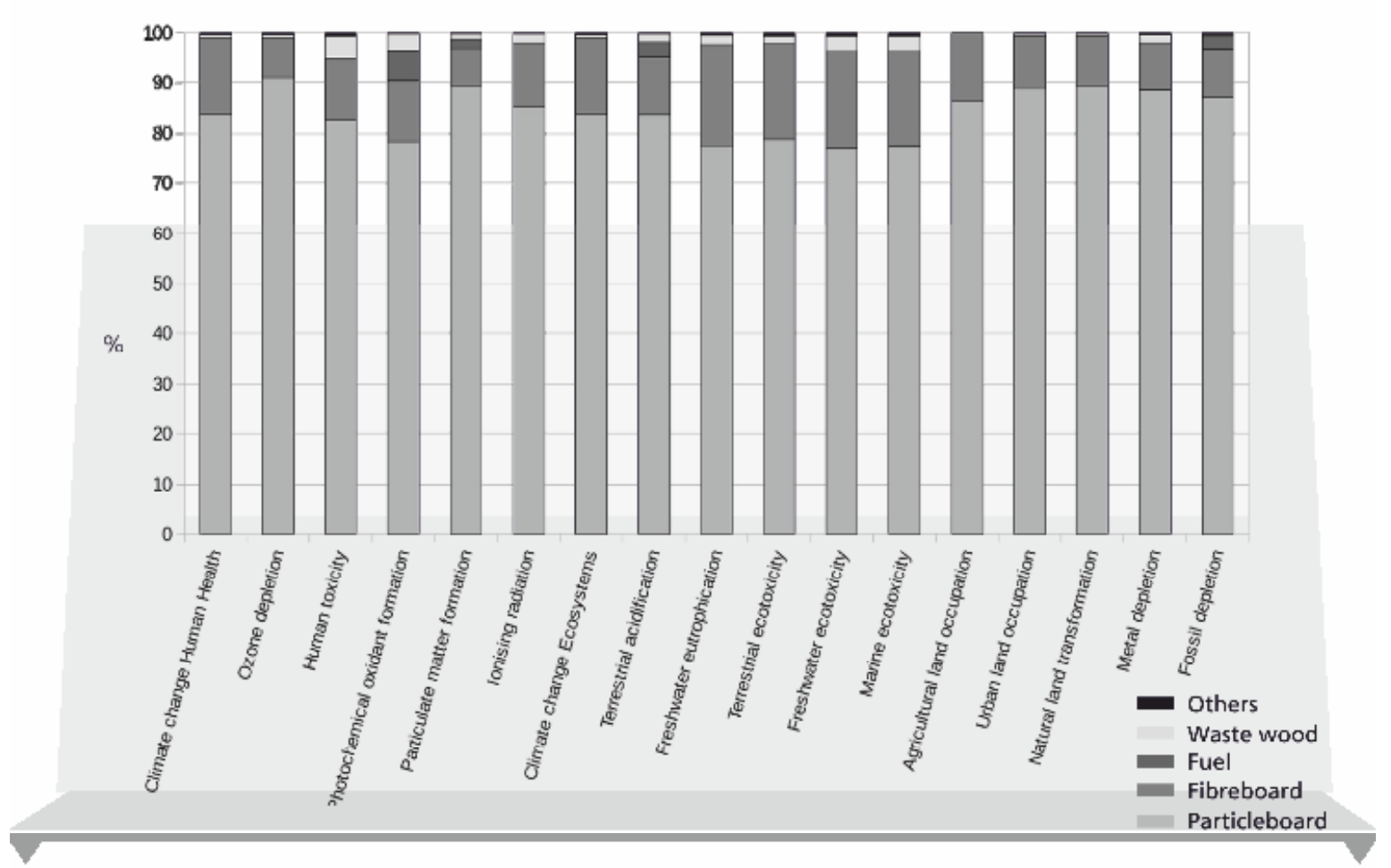

Figure 5. Characterised environmental impact profile of the furniture production system per yearly production

Source: own study 
depletion, human toxicity, photochemical oxidant formation, particulate matter formation, ionising radiation, terrestrial acidification, freshwater eutrophication, terrestrial ecotoxicity, freshwater ecotoxicity, marine ecotoxicity, agricultural land occupation, urban land occupation, natural land transformation, metal depletion and fossil depletion (Goedkoop et al. 2013, pp. 1-20).

A characterised environmental profile of the furniture production system revealed that the particleboard and the fibreboard have the most detrimental impact on the environment (see figure 5). In all impacts categories, besides photochemical oxidant formation, it exceeds $95 \%$. On the other hand, despite the suggestion of EIA made with the use of traditional methods that waste, airborne emissions and noise form the main environmental nuisances of planned furniture plant, they are responsible for less than $5 \%$ of environmental impacts in all impact categories. This proves that the optimisation of the use of the raw materials during the furniture production process and the searching for the raw materials alternatives ought to be at the forefront of activities aiming at the reduction of the environmental impacts.

A normalised environmental profile of the furniture production system has revealed that it generates the largest negative impact in the area of protection of

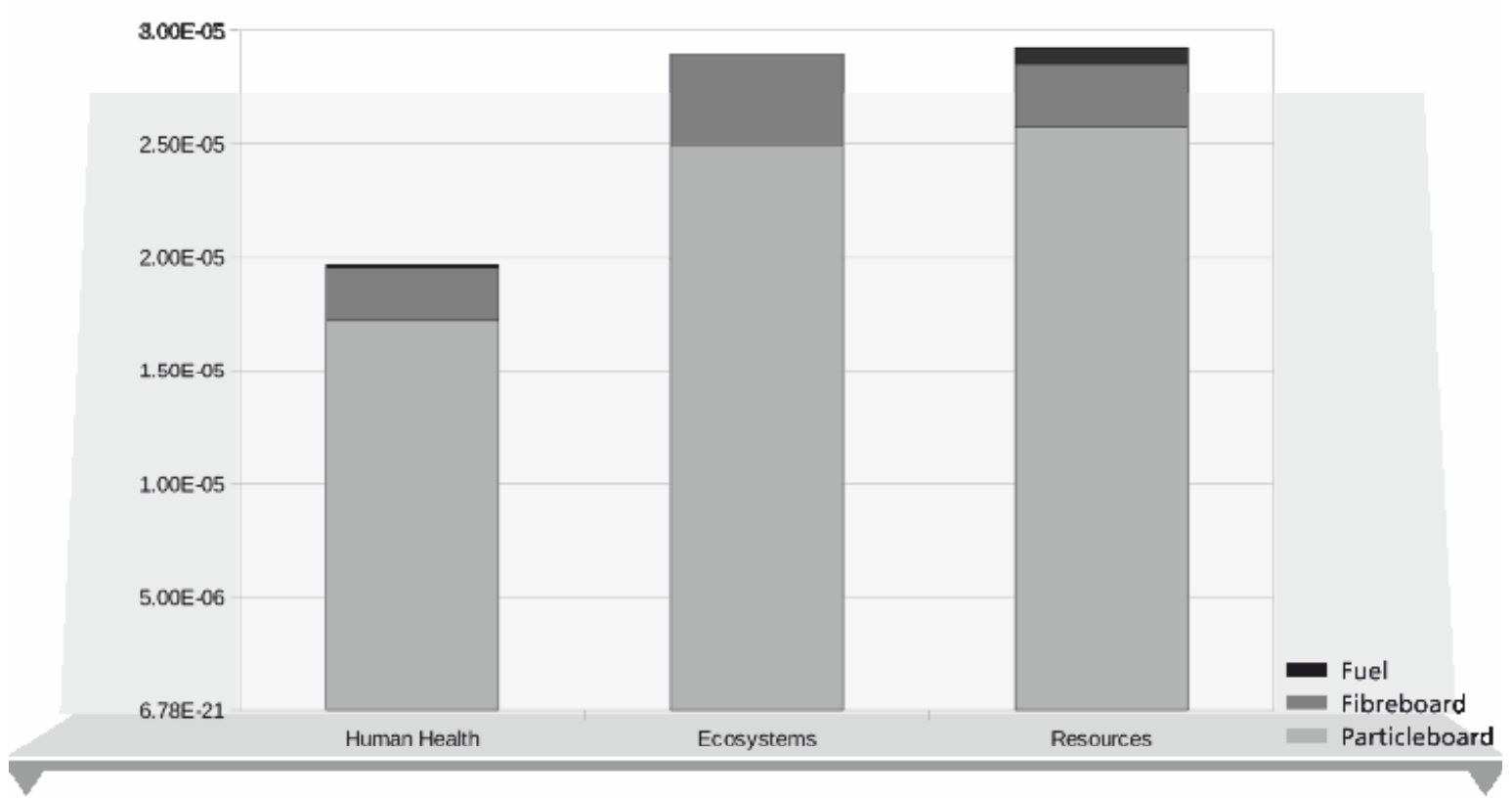

Figure 6. Normalised environmental impact profile of the furniture production system per yearly production

Source: own study 
resources (2,95E-5), followed by ecosystems (2,90E-5) and human health $(1,9 \mathrm{E}-5)$ (see figure 6). Considering the fact that particleboard and the fibreboard, and thus related to them the processes of wood logging and boards production, have the most detrimental impact on the environment, one can expect the above presented results.

\subsection{Integrated EIA - LCA approach}

Following the overview of LCA results presented in the previous sections 3.1.1-3.1.3, this section aims to discuss how LCA techniques can be integrated into the EIA process to enhance its quality and completeness. The discussion will focus on selected steps of the EIA process, including scoping, consideration of project alternatives and assessment of impact significance, to point out the potential benefits from integrating LCA into these steps. It should be noted that this discussion is not intended to be exhaustive or comprehensive, but rather to illustrate a few of the most important benefits. There are undoubtedly further potential benefits that can be achieved by applying LCA methodology in various steps of the EIA process.

Scoping is the second step in the EIA process that is initiated following the positive decision about the necessity of EIA made during the screening. While the requirements and guidelines for scoping may vary in different systems of EIA, a general principle is that the scoping is a composite procedure with several outcomes, which, taken together, establish the terms of reference for the subsequent assessment process and help concentrateing on the most relevant issues and concerns. In particular, these outcomes include: identification of feasible and practical project alternatives for further analysis; identification of valued ecosystem components; establishment of the spatial and temporal boundaries of the assessment; identification of key impacts that should be addressed in an environmental assessment (Noble 2010).

The process of impact identification involves analysis of the proposed project activities during its construction, operation and decommissioning phases, as well as their potential effect on various components of the environment. In this context, environmental impacts can be described as "any change in the physical, natural or cultural environmental brought about by a development project" (European Commission 2001). Identification of potential impacts in scoping is typically performed as a combination of professional judgement, public consultations, scoping checklists and matrices (Noble 2010). Taking 
the furniture production plant as an example, the outcomes of the goal and scope definition phase of LCA described in section 3.1.1 can support these "classical" scoping methods by providing detailed information about the planned production process, from operations in the production hall to storage and shipping, as well as substances used in the production of furniture (e.g. adhesives, paraffin emulsion, dyes). Results of the inventory analysis phase outlined in section 3.1.2 will help to establish the link between project activities and environmental components in form of a detailed analysis of inputs (i.e. energy, heat, materials and substances) and outputs (i.e. noise, waste, airborne emissions) of the production system as shown in figure 4. Finally, results of the impact assessment phase presented in section 3.1.3 include a specific description of the affected environmental components and corresponding impact categories. Collectively, this information will provide a valuable assistance in completing the scoping checklists and matrices to clearly display the relationship between project activities and potential changes in the baseline condition of the affected environmental components (i.e. identification of direct impacts of the proposed project). Furthermore, description of the whole range of upstream and downstream processes (besides operation of the furniture plant itself) performed during the goal and scope definition phase of LCA will assist the identification of indirect, cumulative and synergistic impacts. Such impacts cannot be effectively identified with the help of checklists and matrices and require application of more complex methods, such as network analysis or systems modelling.

Consideration of feasible and practical project alternatives identified during the scoping step is a central element of good EIA practice and can be even described as a heart of EIA process. Pursuing a more favourable alternative can help to completely avoid some environmental impacts or significantly reduce their significance. In general, we can distinguish between two broad types of alternatives: alternatives to the project (i.e. meeting development objectives through a functionally different type of the project), and alternative means to carry out the project (Noble 2010, p. 85). In practice, alternatives to the project are rarely considered at the level of EIA and are a typical focus of strategic development planning and strategic environmental assessment (SEA). Alternative means to implement the project are referred to alternative location (e.g. of the project site) and alternative project design. Consideration of the most preferable alternative means, including both location and design alternatives, can greatly benefit from LCA results. More specifically, LCA can support the process of analysing and comparing project alternatives by

Life Cycle Assessment (LCA)

in Environmental Impact Assessment (EIA): principles and practical implications for industrial projects 
providing quantitative data about potential impacts of the project, including their predicted magnitude or scale, for each of the analysed alternatives. For example, inventory analysis phase of LCA can provide data about inputs and outputs of production systems with different process design. And impact assessment phase of LCA can inform EIA team about the magnitude of environmental impacts belonging to various impact categories that can be calculated for several technological or location alternatives. However, to effectively support the process of alternatives consideration, an LCA study would need to be conducted for each of the identified feasible alternatives. Obviously, a series of LCA studies would require additional resources, which can be considered as a limitation.

As was already mentioned in the introduction, assessment of significance of environmental impacts relies mostly on experience and expert opinion. Despite being fast and flexible, such pragmatic approach can be considered as a major weakness in the common EIA practice because it leaves a lot of place for potential mistakes due to poor (or biased) judgement and a lack of credible scientific evidence. In a simplified way, impact significance can be defined as a function of: (1) impact characteristics, i.e. magnitude or the degree of change in the baseline condition of an environmental component, duration, frequency, spatial distribution, reversibility, etc.; and (2) impact importance, i.e. value of the environmental receptor, its sensitivity, resilience, scarcity, stability, capacity, etc. (Lawrence 2007). Integration of LCA will help to add a much needed credibility and reduce uncertainties in the assessment of impact significance by providing, for example, quantitative data about the likely magnitude of environmental impacts, which is calculated during the impact assessment phase of LCA.

\section{Conclusions}

EIA is a globally applied, legally formalised, decision-making process for ensuring that environmental concerns are taken into account in the development stage of projects. Whereas LCA is a globally applied, formalised by standards, decision supporting technique for the evaluation of environmental impacts from the life cycle perspective. Consequently, LCA ought to be perceived as a chance for more in-depth, in a global context, evaluation of environmental impacts in the EIA process.

The results of the conducted research has have proved that integrating the LCA technique in the EIA process of industrial projects can bring numerous 
advantageous, namely: a significant improvement of the quality of the environmental impact assessment, a linking of man-made interventions to their environmental consequences either at the midpoint or endpoint level that is the requirement of the latest release of the EIA Directive 2014/92/EU and finally life cycle perspective, and thus preventing the responsibility for environmental impacts from shifting between business entities.

Observing the current trends in perceiving and determining the environmental impacts, one can expect that LCA becomes a recommended technique in the EIA process, especially in case of projects that may have many indirect impacts on the environment in the entire production system. As to make it possible, however, further in-depth discussion is necessary. Consequently, forthcoming collaborative study on LCA application in EIA, regarding different types of projects and variants of LCA analysis, is planned.

\section{Acknowledgements}

This study was supported by DAAD (Deutscher Akademischer Austauschdienst), funding programme ID: 57314019.

\section{Summary}

\section{Life Cycle Assessment (LCA) in Environmental Impact Assessment (EIA): principles and practical implications for industrial projects}

This article discusses the theoretical and practical aspects of the application of the life cycle assessment (LCA) technique in the environmental impact assessment (EIA) process. LCA enables to consider the environmental impacts of the whole production system, including upstream and downstream processes and to estimate their consequences already at the project planning stage. It was illustrated using the case study of the planned furniture production plant representing the industrial sector. The conventional simplified cradle-to-gate LCA analysis, using SimaPro software and the ReCiPe Endpoint method, was performed. It revealed that unlike the findings of EIA made with the support of traditional methods, not waste, airborne emissions and noise, but the particleboard and the fibreboard used by the planned furniture production plant have the most detrimental impact on the environment in all impact categories. The greatest 
damage it causes in the areas of protection of resources followed by ecosystems. The research proved high applicability of EIALCA approach for the evaluation of the environmental impacts of planned industrial projects.

Keywords: environmental impact assessment, EIA, life cycle assessment, LCA, furniture manufacturing.

\section{Streszczenie}

Zastosowanie Oceny Cyklu Życia (LCA) w Ocenie Oddziaływania na Środowisko (OOŚ): podstawowe założenia i wykorzystanie $\mathrm{w}$ projektach przemysłowych

$\mathrm{W}$ artykule omówiono teoretyczne i praktyczne aspekty stosowania techniki oceny cyklu życia (LCA) w procesie oceny oddziaływania na środowisko (OOŚ). LCA umożliwia uwzględnienie wpływu całego systemu produkcyjnego na środowisko, $\mathrm{w}$ tym również procesów powiązanych $\mathrm{z}$ etapem łańcucha dostaw, użytkowania i zagospodarowania odpadów oraz oszacowanie ich skutków dla środowiska już na etapie planowania projektu. Zostało to zilustrowane na podstawie studium przypadku - rozbudowy zakładu produkcji mebli. W tym celu wykonano konwencjonalną uproszczoną analizę LCA od kołyski do bramy, przy wykorzystaniu oprogramowania SimaPro i metody ReCiPe Endpoint. Badania wykazały, że w przeciwieństwie do wyników OOŚ wykonanej przy użyciu tradycyjnych metod, to nie wytwarzanie odpadów, emisja zanieczyszczeń oraz hałas stanowić będą największe obciążenie dla środowiska, wynikające $\mathrm{z}$ eksploatacji powstającego zakładu produkcji mebli, ale zużycie zasobów (płyty wiórowej i płyty pilśniowej) ma najwyższy procentowy udział we wszystkich kategoriach wpływu. Największe szkody wywołuje w obszarach zużycie zasobów oraz ekosystemów. Badania wykazały wysoką przydatność podejścia EIA-LCA do oceny wpływu na środowisko planowanych projektów przemysłowych.

Słowa

kluczowe: ocena oddzialywania na środowisko, OOŚ, ocena cyklu życia, LCA, produkcja mebli. 
JEL

\section{Classification: Q51, Q55, Q56}

\section{References}

1. Dąbel, A. and Łyszczarz, M. (2016), Analiza LCA dla dróg i mostów jako narzędzie do szczegółowej i kompleksowej oceny oddziaływania na środowisko, Budownictwo i Architektura 15(1), 41-50.

2. Directive 2011/92/EU of the European Parliament and of the Council of 13 December 2011 on the assessment of the effects of certain public and private projects on the environment.

3. Directive 2014/52/EU of the European Parliament and of the Council of 16 April 2014 amending Directive 2011/92/EU on the assessment of the effects of certain public and private projects on the environment.

4. European Commission (2001), Guidance on EIA - Scoping, June 2001, Luxembourg: Office for Official Publications of the European Communities.

5. Jain, R.K., Urban, L.V., Stacey, G.S., Balbach H.E. and Webb M.D. (2001), Environmental Assessment, New York: McGraw-Hill.

6. Guinee J. B. (ed.) (2004), Handbook on Life Cycle Assessment. Operational Guide to the ISO Standards, New York, Boston, Dordrecht, London, Moscow: Kluwer Academic Publishers.

7. Glasson, J., Therivel, R., Chadwick, A. (2005), Introduction to environmental impact assessment, 3rd edition, London and New York: Routledge.

8. Goedkoop, M., Heijungs, R., Huijbregts, M., De Schryver, A., Struijs, J. and Zelm, R. (2013), ReCiPe 2008 A life cycle impact assessment method which comprises harmonised category indicators at the midpoint and the endpoint level. Ministry of Housing, Spatial Planning and Environment (VROM).

9. International Standard ISO 14040:2006. Environmental management Life cycle assessment - Principles and framework.

10. International Standard ISO 14044:2006. Environmental management Life cycle assessment - Requirements and guidelines.

11. International Standard ISO 14001:2015. Environmental management systems - Requirements with guidance for use.

12. Larrey-Lassalle, P., Catel, L., Roux, P., Rosenbaum, R., Lopez-Ferber, M., Junqua, G. and Loiseau, E. (2017), An innovative implementation of LCA within the EIA procedure: Lessons learned from two Wastewater Treatment Plant case studies, Environmental Impact Assessment Review, 63 (2017), 95-106.

13. Lawrence, D.P. (2007), Impact significance determination - back to basics, Environmental Impact Assessment Review, 27 (2007) 755-769.

14. Lenzen, M., Murray, S., Korte, B. and Dey C. (2003), Environmental impact assessment including indirect effects - a case study using input - output analysis, Environmental Impact Assessment Review, 23 (3), 263-282. 
15. Li, X., Zhu, Y. and Zhang, Z. (2010), An LCA-based environmental impact assessment model for construction processes, Building and Environment, 45 (2010) 766-755.

16. Manuilova, A., Suebsiri, J., Wilson, M. (2009), Should Life Cycle Assessment be part of the Environmental Impact Assessment? Case study: EIA of $\mathrm{CO}_{2}$ Capture and Storage in Canada, Energy Procedia, 1 (1), 4511-4518.

17. Noble, B.F. (2010), Introduction to environmental impact assessment: A guide to principles and practice, 2nd edition, Don Mills, Ontario: Oxford University Press.

18. Rybaczewska-Błażejowska, M. (2017), Life cycle perspective - a new requirement of environmental management systems, [in:] Knosala R. (ed.), Innowacje w Zarządzaniu i Inżynierii Produkcji, Polskie Towarzystwo Zarządzania Produkcją, Opole, 98-106.

19. Steinemann, A. (2001), Improving alternatives for environmental impact assessment, Environmental Impact Assessment Review, 21 (1), 3-21.

20. Tukker, A. (2000), Life cycle assessment as a tool in environmental impact assessment, Environmental Impact Assessment Review, 20 (2000) 435-456. 